\title{
Combustion Characteristics of Sewage Sludge and Algae
}

\author{
Yaman Kumar Sahu, Pravin Kumar Sahu, Suryakant Chakradhari, \\ Khageshwar Singh Patel* \\ School of Studies in Chemistry/Environmental Science, Pt. Ravishankar Shukla University, Raipur, India \\ Email: "patelks_55@hotmail.com
}

Received 7 March 2016; accepted 18 April 2016; published 21 April 2016

Copyright (C) 2016 by authors and Scientific Research Publishing Inc.

This work is licensed under the Creative Commons Attribution International License (CC BY).

http://creativecommons.org/licenses/by/4.0/

c) (i) Open Access

\begin{abstract}
Sewage sludge is a good source of energetically desirable compounds and green algae in developing country like India. In this work, the combustion characteristics of sewage sludge and green algae are described. The calorific value $(\mathrm{CV})$ of dried sewage sludge $(n=7)$ and green algae $(n=11)$ was ranged from 1800 to 6250 and 3700 to $6280 \mathrm{kcal} / \mathrm{kg}$ with mean value of $3999 \pm 1347$ and $4428 \pm 547 \mathrm{kcal} / \mathrm{kg}$, respectively. The effect of proximate variables and water quality parameters in the $\mathrm{CV}$ of sludge and algae are discussed.
\end{abstract}

\section{Keywords}

Sewage Sludge, Algae, Water Quality, Caloric Value

\section{Introduction}

Sewage sludge includes black and grey water and semi-solid precipitates released at the household levels. Total sewage generated from urban centres in India is $\approx 4.0 \times 10^{10} \mathrm{~L} /$ day. The sewage sludge is a source of nutrients and pathogenic microbes. The sewage sludge is covered by the algal bloom in urban sectors of India. Algal bloom causes tastes and odors in the water. Some algae produce an aromatic odor resembling to that of particular flowers or vegetables. In addition, a spicy, a fishy odor and a grassy odor can also be produced by algae [1]. Sewage is a source of biomass energy that is very similar to the animal wastes. The caloric value of the sewage and algae was reported by many researchers [2]-[11]. In this work, the caloric value of sludge and algal bloom of sewage reservoirs of Raipur city, CG, India is described for their further uses in energy generation.

"Corresponding author. 


\section{Material and Methods}

\subsection{Study Area}

Raipur is a capital city of Chhattisgarh state of India, growing rapidly in unsustainable order due to being commercial center for steel, cement and forest products. At least two million habitants are living in this city over $\approx 1.0 \times 10^{3} \mathrm{~km}^{2}$ area by discharging $\approx 3.0 \times 10^{7} \mathrm{~L} /$ day waste water. They are dumped into seven open reservoirs constructed in the outer of city, Figure 1 . The area of sewage reservoirs is ranged from $2-4 \mathrm{~km}^{2}$. Among them, two reservoirs i.e. Urla and Siltara lie in the industrial area.

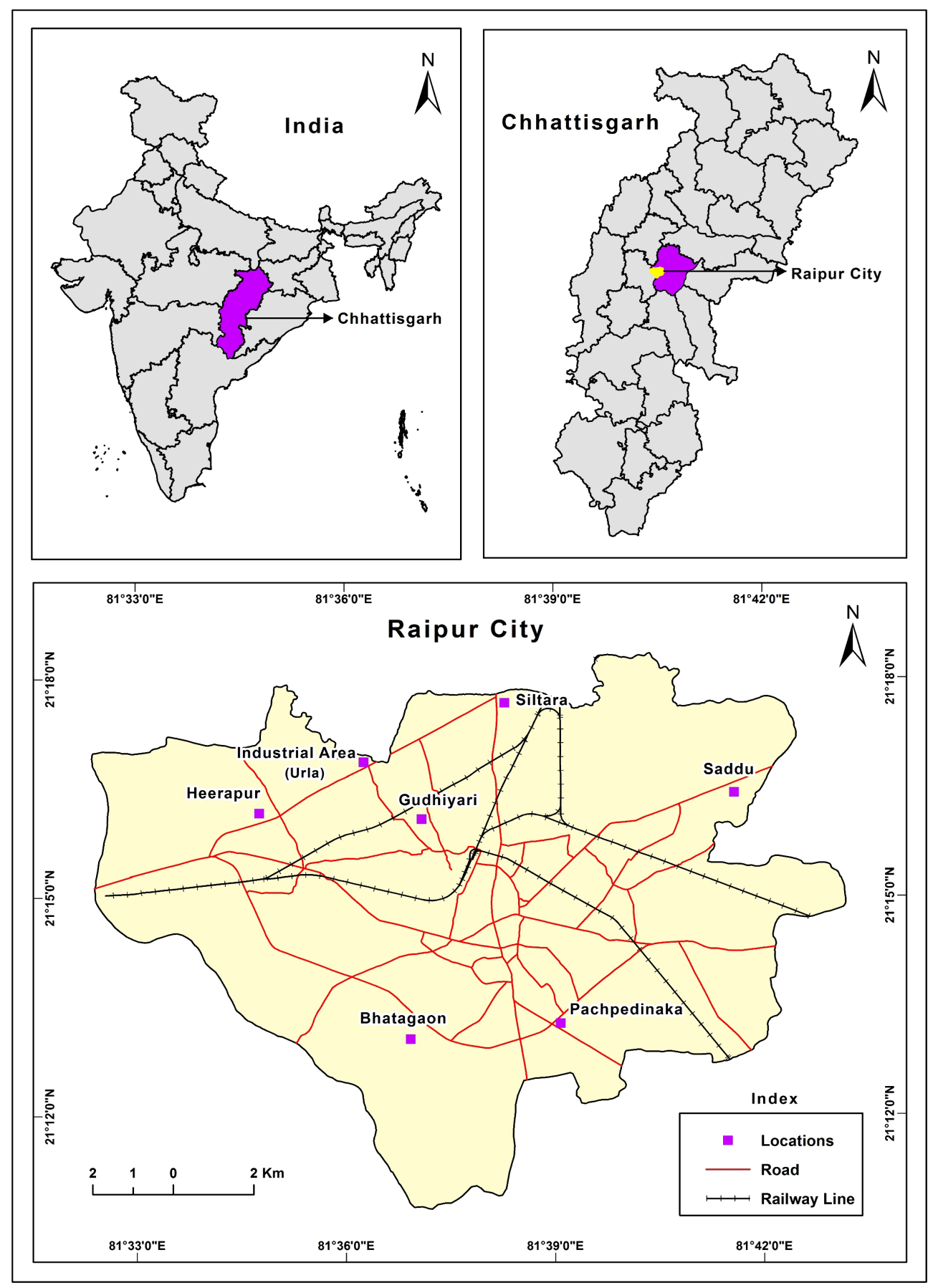

Figure 1. Representation of location of sewage ponds in Raipur city, India. 


\subsection{Sample Collection}

The composite water sample $(100 \times 5 \mathrm{~mL}$ from five points of each location) was collected into glass bottles (500-mL) in January 2016 as prescribed in the literature [12]. The floating algal biomass was collected manually by use of knife in a 1-L glass beaker from the waste water by subsequent washing with deionized water thrice. One kilogram of the top composite sewage sludge from five points of each location $(0-10 \mathrm{~cm})$ was taken from seven reservoirs in January 2016 by use of a stainless steel spoon and stored in a glass jar [13]. The sewage sludge and algal biomass were dried for 2 days. Thereafter, they were dried in an oven for 2 days at $50^{\circ} \mathrm{C}$ to remove the moisture. The dried mass was crushed and sieved out particles of $<0.25 \mathrm{~mm}$ for the combustion studies.

\subsection{Analysis}

The physical parameters i.e. temperature ( $\mathrm{T}$ ), $\mathrm{pH}$, electrical conductivity (EC), dissolved oxygen (DO) and reduction potential (RP) values of the water were measured at spot by Hanna made sensors. The total hardness (TH) and total alkalinity (TA) values of the filtered water were determined by the titration methods in the laboratory. The $\mathrm{F}^{-}$content of water was analyzed by using the Metrohm-720 ion selective electrode in the presence of the buffer. The content of ions i.e. $\mathrm{Cl}^{-}, \mathrm{NO}_{3}^{-}, \mathrm{SO}_{4}^{2-}, \mathrm{NH}_{4}^{+}, \mathrm{Na}^{+}$and $\mathrm{K}^{+}$in water and sludge were analyzed by Dionex-1100 ion chromatography. A $0.25 \mathrm{~g}$ of the sludge sample was digested with acids ( $3 \mathrm{~mL} \mathrm{HCl}$ and $1 \mathrm{~mL}$ $\mathrm{HNO}_{3}$ ) in a closed system with P/T MARS CEM (Varian Company) microwave oven for use of metal analysis. The metals (i.e. $\mathrm{Cr}, \mathrm{Fe}, \mathrm{Mn}, \mathrm{Ni}, \mathrm{Cu}$ and $\mathrm{Zn}$ ) in the extract were analyzed by the Varian ICP-OES-700-ES.

The bulk density (BD) was measured by the water replacement method [14]. The moisture content of the tree samples were analyzed by heating it at $105^{\circ} \mathrm{C} \pm 2^{\circ} \mathrm{C}$ till constant weight is observed. The ash content of the materials was determined by heating the sample at $600^{\circ} \mathrm{C}$ for $4 \mathrm{hr}$ [15]. The calorific value (CV) of the sample was determined experimentally using a Digital Microprocessor Based Bomb Calorimeter UTS 1.34, Advance Research Instruments Co., New Delhi as described in the literature [16]. The calorific value was calculated by using the following equation:

$$
\mathrm{GCV}=\left[\{\mathrm{We} \Delta \mathrm{T}\}-\left\{\mathrm{W}_{1}(4.18)+\mathrm{W}_{2}(0.335)\right\}\right] / \mathrm{M}
$$

where, GCV, M, We, $\mathrm{W}_{1}, \mathrm{~W}_{2}$ and $\Delta \mathrm{T}$ represent gross calorific value of species (kcal/kg), water equivalent, weight of sample, weight of cotton thread, weight of fuse wire and rise in temperature, respectively.

The content of volatile compounds including moisture was analyzed by using a Metller thermogravimetric analyzer-TGA-2 at heating rate of $20^{\circ} \mathrm{C} / \mathrm{min}$.

The value of non-volatile (fixed) carbon (FC) was computed by subtracting the fraction (\%) of moisture (MC), volatile compounds (VCs) and ash residue (AR) to the 100 .

$$
\mathrm{FC} \%=100-\{(\mathrm{MC}+\mathrm{VCs}+\mathrm{AR}) \%\}
$$

\section{Results and Discussion}

Algae are main primary byproducts in all kinds of water bodies due to eutrophication, and being indicators of water pollution in a number of significant ways due to availability of contained nutrients. Algae are among the fastest-growing plants in the world and have much faster growth-rates than terrestrial crops. All sewage sludge reservoirs of country like India are floated with different types of algal blooms due to variations in the topology and exposure extent of sun light and nutrient levels.

\subsection{Water Quality}

The water quality of seven sewage reservoirs of Raipur city is shown in Table 1, Table 2. The water of all reservoirs is colored with bad smell due to loading of biodegradable organics. The value of T, pH, EC, DO and RP of the water bodies $(n=7)$ was ranged from $28-33^{\circ} \mathrm{C}, 6.6-9.4,720-1543 \mu \mathrm{S} / \mathrm{cm}, 5.9-7.4 \mathrm{mg} / \mathrm{L}$ and $90-220$ $\mathrm{mV}$ with mean value of $30 \pm 2^{\circ} \mathrm{C}, 7.2 \pm 0.7,1108 \pm 262 \mu \mathrm{S} / \mathrm{cm}, 7.0 \pm 0.4 \mathrm{mg} / \mathrm{L}$ and $137 \pm 34 \mathrm{mV}$, respectively. The concentration of $\mathrm{F}^{-}, \mathrm{Cl}^{-}, \mathrm{SO}_{4}^{2-}, \mathrm{NO}_{3}^{-}, \mathrm{PO}_{4}^{3-}, \mathrm{NH}_{4}^{+}, \mathrm{Na}^{+}, \mathrm{K}^{+}, \mathrm{Fe}, \mathrm{TH}$ and $\mathrm{TA}$ was ranged from $0.9-1.7$, 48 - 84, 22 - 56, 490 - 690, 4.5 - 8.4, 7 - 13, 90 - 167, 27 - 70, 0.3 - 0.6, 240 - 360 and 340 - $720 \mathrm{mg} / \mathrm{L}$ with mean value of $1.3 \pm 0.2,62 \pm 9,41 \pm 9,606 \pm 63,6.6 \pm 1.2,10 \pm 2,136 \pm 22,46 \pm 13,0.4 \pm 0.1,299 \pm 34$ and $505 \pm$ 
$101 \mathrm{mg} / \mathrm{L}$, respectively. The highest value for the most of chemical parameters was seen in the water of reservoirs lie in the industrial area i.e. Urla and Siltara, Figure 2. These water bodies are bloomed with multiple algal biomass i.e. microcystis, hydrodictyon and phithophora.

\subsection{Combustion Characteristics of Sewage Sludge}

All sewage sludge was colored with bad smell as shown in Table 3 . The dried surface sewage sludge were found to be contaminated with nutrients i.e. $\mathrm{P}, \mathrm{S}, \mathrm{Cl}, \mathrm{K}, \mathrm{Cr}, \mathrm{Mn}, \mathrm{Fe}, \mathrm{Ni}, \mathrm{Cu}$ and $\mathrm{Zn}$ at elevated levels, ranging from 455 - 718, 941 - 1415, 328 - 471, 8474 - 10,286, 210 - 355, 1206 - 1521, 50,837 - 57,931, 57 - 113, 204 449 and $472-837 \mathrm{mg} / \mathrm{kg}$ with mean value of $570 \pm 60,1191 \pm 128,381 \pm 37,9203 \pm 431,272 \pm 36,1370 \pm 81$, 54,779 \pm 1688, $80 \pm 13,294 \pm 63$ and $623 \pm 93 \mathrm{mg} / \mathrm{kg}$, respectively. The bulk density (BD), moisture content

Table 1. Physical characteristics of sewage water.

\begin{tabular}{ccccccccccc}
\hline S. No. & Location & Smell & Color & $\mathrm{T},{ }^{\circ} \mathrm{C}$ & $\mathrm{pH}$ & $\mathrm{EC}$ & $\mathrm{RP}$ & DO & Algal species in encountered \\
\hline 1 & Gudhiyari & Fishy & $\mathrm{BG}$ & 29 & 7.3 & 730 & 170 & 7.3 & Lyngbya spp., Phithophora spp. \\
2 & Bhatagaon & Unpleasant & $\mathrm{BBr}$ & 28 & 6.6 & 824 & 150 & 7.4 & Microcystis spp. \\
3 & Saddu Mowa & Unpleasant & $\mathrm{BBr}$ & 29 & 6.8 & 1120 & 120 & 6.5 & Phithophora spp. \\
4 & Urla & Fishy & $\mathrm{BG}$ & 33 & 6.6 & 1543 & 90 & 5.9 & $\begin{array}{c}\text { Microcystis spp., Hydrodictyon spp., } \\
\text { Phithophora spp. }\end{array}$ \\
5 & Siltara & Unpleasant & BG & 33 & 9.4 & 1380 & 100 & 7.2 & Hydrodictyon spp., Phithophora spp. \\
6 & Heerapur & Fishy & BG & 30 & 6.6 & 1440 & 220 & 7.4 & Lyngbya spp. \\
7 & Pachpedinaka & Rotten egg & BG & 28 & 7.1 & 720 & 110 & 7.2 & Phithophora spp. \\
\hline
\end{tabular}

Table 2. Chemical characteristics of sewage water, $\mathrm{mg} / \mathrm{L}$.

\begin{tabular}{ccccccccccccc}
\hline S. No. & $\mathrm{F}^{-}$ & $\mathrm{Cl}^{-}$ & $\mathrm{SO}_{4}^{2-}$ & $\mathrm{NO}_{3}^{-}$ & $\mathrm{PO}_{4}^{3-}$ & $\mathrm{NH}_{4}^{+}$ & $\mathrm{Na}^{+}$ & $\mathrm{K}^{+}$ & $\mathrm{Fe}$ & $\mathrm{TH}$ & $\mathrm{TA}$ \\
\hline 1 & 1.6 & 71 & 40 & 490 & 4.5 & 13 & 90 & 27 & 0.3 & 250 & 340 \\
2 & 0.9 & 60 & 22 & 510 & 5.4 & 10 & 156 & 39 & 0.4 & 270 & 470 \\
3 & 1.2 & 54 & 51 & 610 & 8.1 & 9 & 132 & 33 & 0.5 & 360 & 568 \\
4 & 1.2 & 84 & 48 & 690 & 8.4 & 8 & 167 & 70 & 0.6 & 320 & 720 \\
5 & 1.4 & 53 & 56 & 680 & 7.8 & 13 & 149 & 65 & 0.5 & 340 & 624 \\
6 & 1.0 & 66 & 31 & 690 & 7.2 & 7 & 158 & 57 & 0.4 & 310 & 412 \\
7 & 1.7 & 48 & 38 & 570 & 5.1 & 13 & 101 & 32 & 0.4 & 240 & 403 \\
\hline
\end{tabular}

Table 3. Energy characteristics of dried sewage sludge.

\begin{tabular}{|c|c|c|c|c|c|c|c|}
\hline S. No. & Location & Color & Smell & $\mathrm{BD}, \mathrm{kg} / \mathrm{m}^{3}$ & MC, \% & $\mathrm{CV}, \mathrm{kcal} / \mathrm{kg}$ & $\mathrm{AR}, \%$ \\
\hline 1 & Gudhiyari & $\mathrm{LBr}$ & Dirty & 830 & 4.6 & 1800 & 49 \\
\hline 2 & Bhatagaon & $\mathrm{LBr}$ & Dirty & 870 & 3.5 & 2280 & 45 \\
\hline 3 & SadduMowa & B & Dirty & 980 & 2.8 & 4920 & 43 \\
\hline 4 & Urla & B & Dirty & 1050 & 2.4 & 6030 & 42 \\
\hline 5 & Siltara & B & Dirty & 1080 & 2.1 & 6250 & 41 \\
\hline 6 & Heerapur & DG & Dirty & 950 & 2.9 & 4120 & 44 \\
\hline 7 & Pachpedinaka & $\mathrm{BrB}$ & Dirty & 880 & 3.9 & 2590 & 47 \\
\hline
\end{tabular}

$\mathrm{B}=$ Black, $\mathrm{BrB}=$ Brownish black, $\mathrm{LBr}=$ Light brown, $\mathrm{DG}=$ Dark grey. 


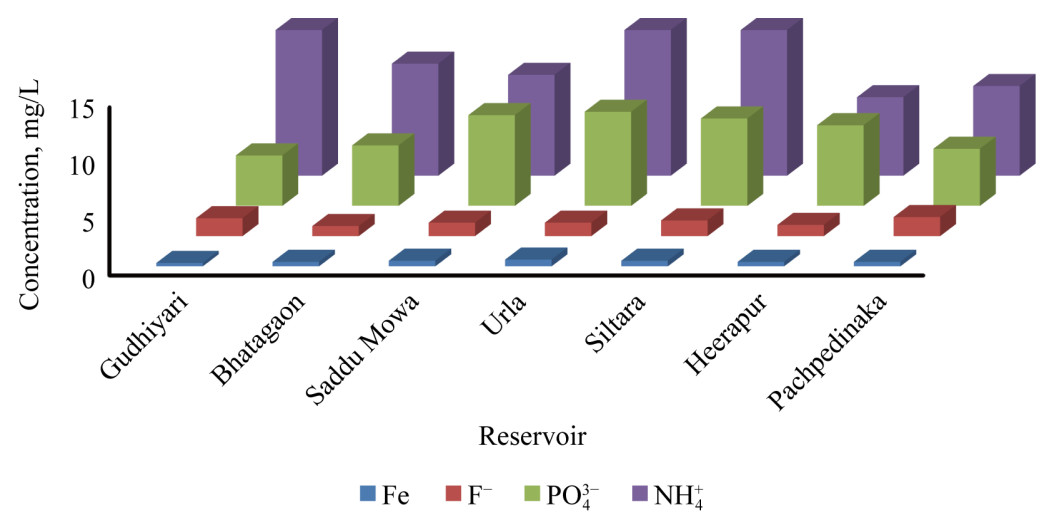

(a)

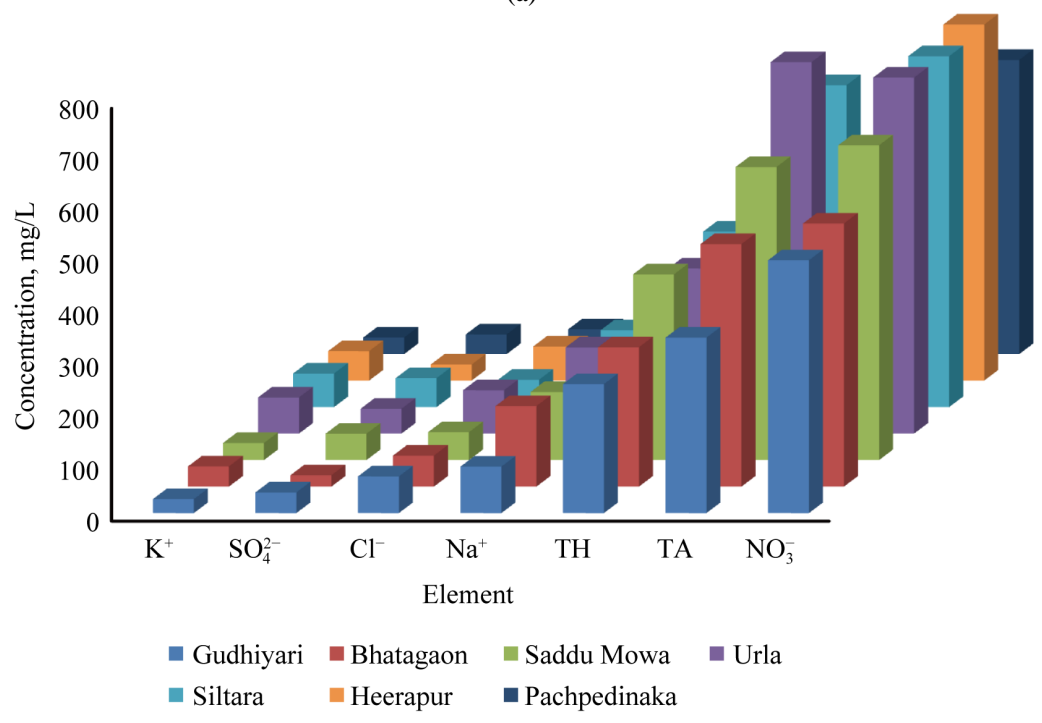

(b)

Figure 2. Spatial variation of concentration of elements in sludge reservoirs.

(MC), calorific value (CV) and ash residue (AR) of sewage sludge of seven reservoirs were ranged from 830 $1080 \mathrm{~kg} / \mathrm{m}^{3}, 2.1 \%-4.6 \%, 1800-6250 \mathrm{kcal} / \mathrm{kg}$ and $41 \%-49 \%$ with mean value of $949 \pm 94 \mathrm{~kg} / \mathrm{m} 3,3.2 \% \pm$ $0.9 \%, 3999 \pm 1818 \mathrm{kcal} / \mathrm{kg}$ and $44 \% \pm 2 \%$, respectively. Among them, the highest calorific value of sludge located in the industrial area i.e. Siltara and Urla was observed, may be due to higher nutrient loading. The CV of the sludge was correlated well $(r=0.99)$ with the nutrient levels and BD unlikely to the MC and AR value, Figure 3. The N, P, S, Na, K, Fe, TH and TA content of the water had fair correlation with CV of the sludge unlikely to halides i.e. $\mathrm{F}^{-}$and $\mathrm{Cl}^{-}$, as shown in Table 4.

\subsection{Combustion Characteristics of Algae}

The combustion characteristics of four algae i.e. hydrodictyon, lyngbya, microcystis, and phithophoragrown in seven reservoirs is shown in Table 5. The value of BD, MC, CV and AR was ranged from $910-1070 \mathrm{~kg} / \mathrm{m}^{3}, 1.5 \%$ - 4.6\%, $3700-6280 \mathrm{kcal} / \mathrm{kg}$ and $1.4 \%-3.8 \%$ with mean value of $963 \pm 32 \mathrm{~kg} / \mathrm{m}^{3}, 3.4 \% \pm 0.6 \%, 4428 \pm 587$ $\mathrm{kcal} / \mathrm{kg}$ and $2.8 \% \pm 0.5 \%$, respectively. The higher CV for hydrodictyon and lyngbya algae was observed, may be due to higher BD value, Figure 4. The CV of algal bloom was correlated well with BD unlikely to the MC and AR, Figure 5. The TGA chromatogram for hydrodictyon algae is shown in Figure 6. The light and heavy volatile compounds (VCs) content of the dried hydrodictyon algae was found to be $5.2 \%$ and $27.4 \%$, respectively. The nonvolatile (fixed) carbon and ash residue content of the algae was computed and found to be $64.8 \%$.

The CV of the dried sewage sludge and algal biomass of the studied area was found to be comparable to other regions of the World [2]-[11]. 


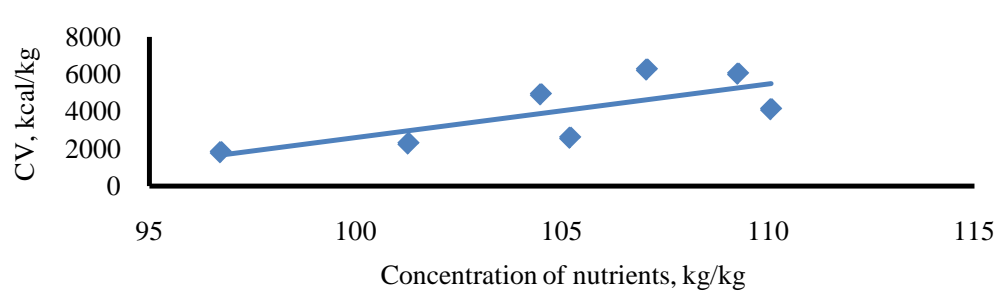

(a)

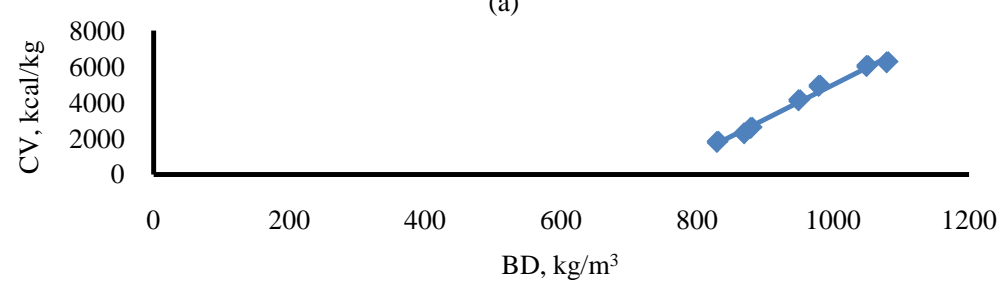

(b)

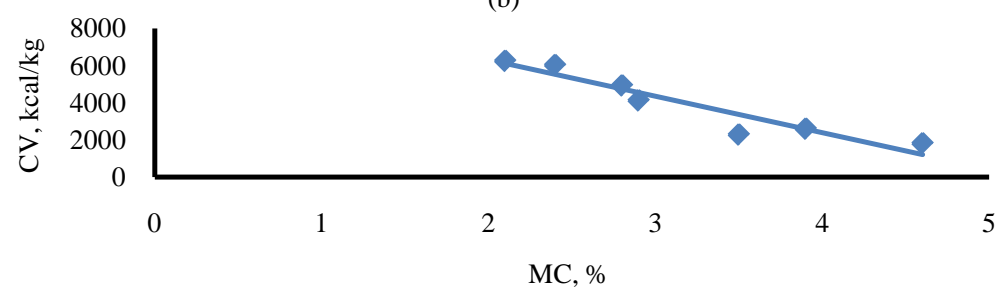

(c)

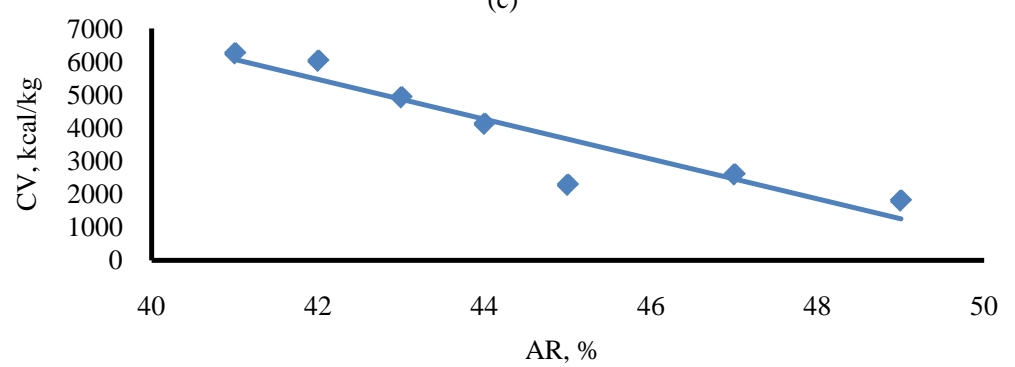

(d)

Figure 3. Correlation of nutrient content, bulk density (BD), moisture content (MC) and ash residue (AR) with calorific value of sewage sludge.

Table 4. Correlation matrix of water parameters and CV.

\begin{tabular}{|c|c|c|c|c|c|c|c|c|c|c|c|c|}
\hline & $\mathrm{F}^{-}$ & $\mathrm{Cl}^{-}$ & $\mathrm{SO}_{4}^{2-}$ & $\mathrm{NO}_{3}^{-}$ & $\mathrm{PO}_{4}^{3-}$ & $\mathrm{NH}_{4}^{+}$ & $\mathrm{Na}^{+}$ & $\mathrm{K}^{+}$ & $\mathrm{Fe}$ & $\mathrm{TH}$ & $\mathrm{TA}$ & $\mathrm{CV}$ \\
\hline $\mathrm{F}^{-}$ & 1.00 & & & & & & & & & & & \\
\hline $\mathrm{Cl}^{-}$ & -0.25 & 1.00 & & & & & & & & & & \\
\hline $\mathrm{SO}_{4}^{2-}$ & 0.42 & -0.03 & 1.00 & & & & & & & & & \\
\hline $\mathrm{NO}_{3}^{-}$ & -0.25 & 0.18 & 0.49 & 1.00 & & & & & & & & \\
\hline $\mathrm{PO}_{4}^{3-}$ & -0.40 & 0.2 & 0.61 & 0.87 & 1.00 & & & & & & & \\
\hline $\mathrm{NH}_{4}^{+}$ & 0.80 & -0.47 & 0.22 & -0.50 & -0.58 & 1.00 & & & & & & \\
\hline $\mathrm{Na}^{+}$ & -0.82 & 0.32 & -0.04 & 0.66 & 0.71 & -0.71 & 1.00 & & & & & \\
\hline $\mathrm{K}^{+}$ & -0.35 & 0.42 & 0.33 & 0.86 & 0.73 & -0.41 & 0.80 & 1.00 & & & & \\
\hline $\mathrm{Fe}$ & -0.26 & 0.24 & 0.58 & 0.73 & 0.88 & -0.42 & 0.67 & 0.71 & 1.00 & & & \\
\hline $\mathrm{TH}$ & -0.42 & 0.03 & 0.62 & 0.70 & 0.93 & -0.47 & 0.67 & 0.53 & 0.72 & 1.00 & & \\
\hline $\mathrm{TA}$ & -0.26 & 0.27 & 0.62 & 0.65 & 0.85 & -0.31 & 0.67 & 0.73 & 0.97 & 0.73 & 1.00 & \\
\hline $\mathrm{CV}$ & -0.20 & 0.15 & 0.73 & 0.88 & 0.95 & -0.34 & 0.64 & 0.81 & 0.89 & 0.86 & 0.88 & 1.00 \\
\hline
\end{tabular}




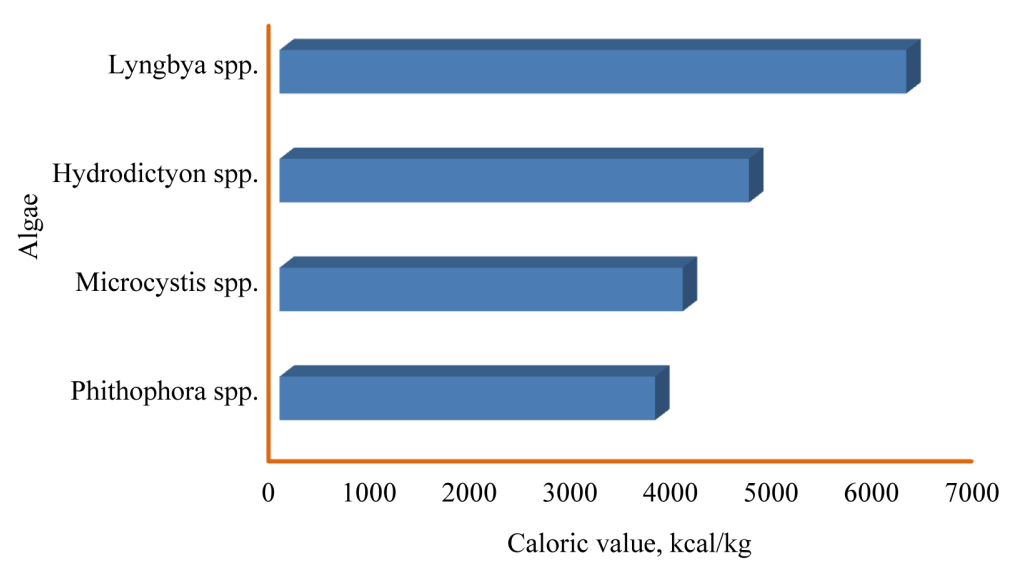

Figure 4. Calorific value of various algal bloom.

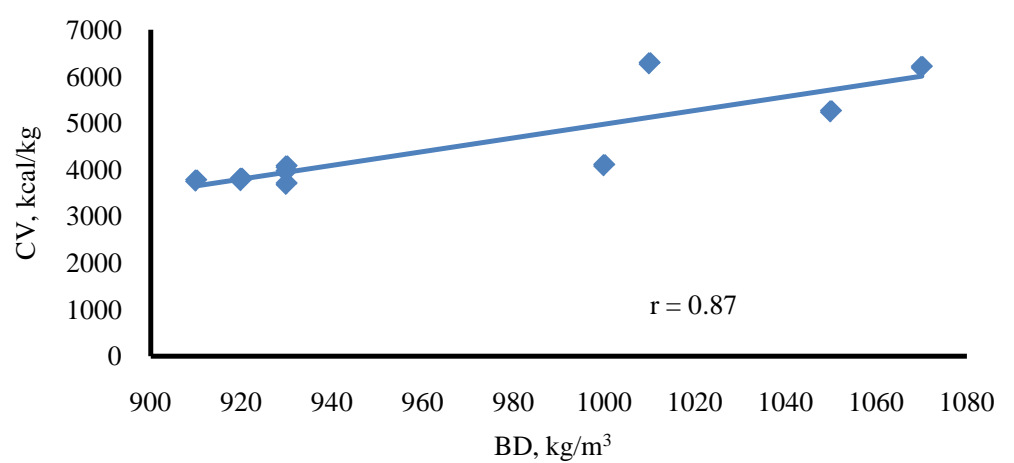

(a)

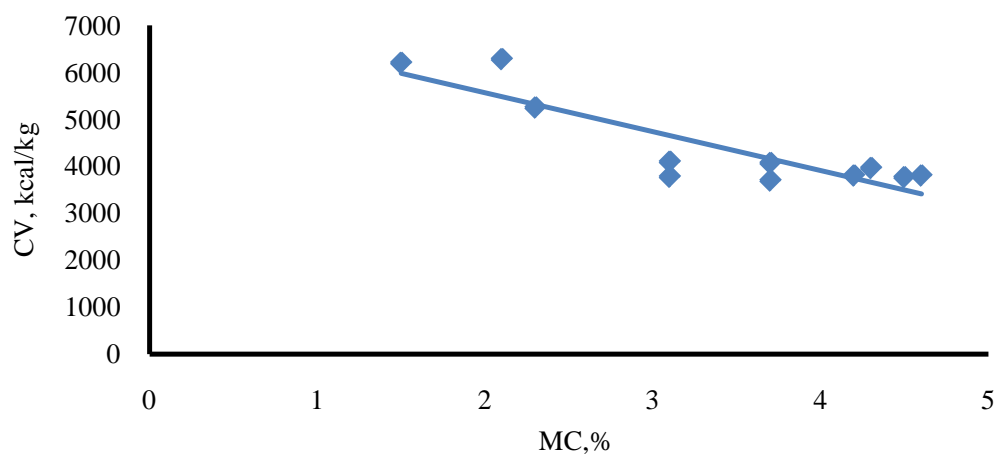

(b)

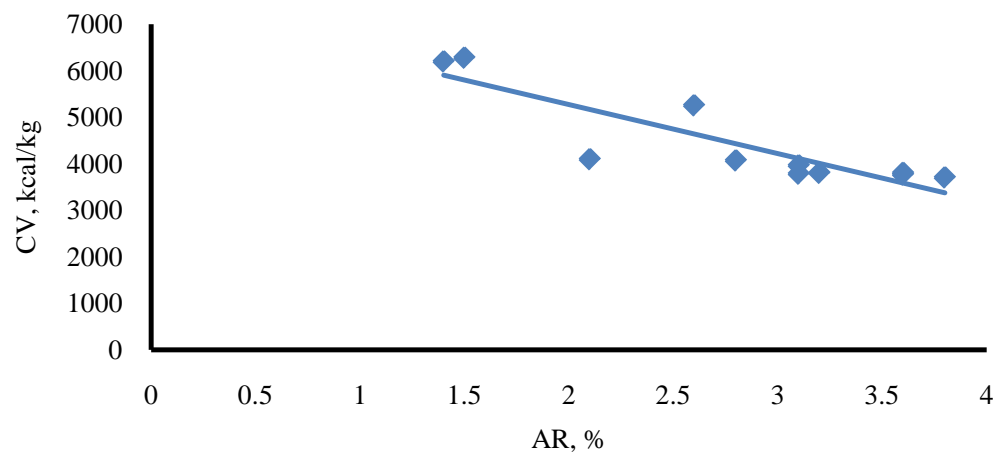

(c)

Figure 5. Correlation of BD, MC and AR with calorific value of algal bloom. 


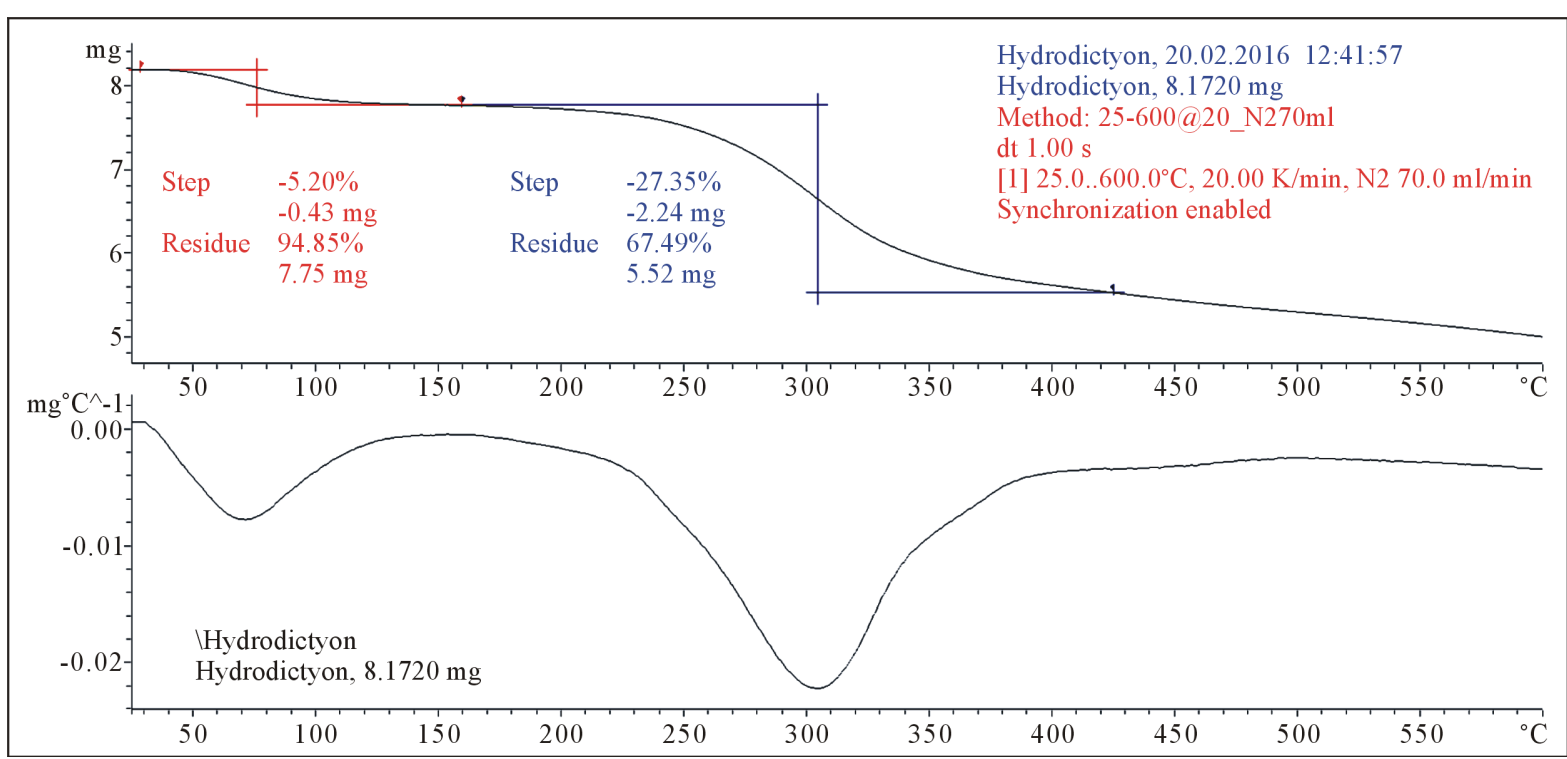

Figure 6. TGA chromatogram of Hydrodictyon spp.

Table 5. Energy characteristics of dried algae.

\begin{tabular}{|c|c|c|c|c|c|c|c|c|}
\hline S. No. & Location & Algae & Color & Type of AB & $\mathrm{BD}, \mathrm{kg} / \mathrm{m}^{3}$ & MC, \% & $\mathrm{CV}, \mathrm{kcal} / \mathrm{kg}$ & AR, \% \\
\hline \multirow[t]{2}{*}{1} & Gudhiyari & Lyngbya spp. & $\mathrm{Gr}$ & MF & 1010 & 2.1 & 6280 & 1.5 \\
\hline & Gudhiyari & Phithophora spp. & $\mathrm{Gr}$ & MF & 920 & 4.2 & 3800 & 3.2 \\
\hline 2 & Bhatagaon & Microcystis spp. & $\mathrm{BGr}$ & SF & 930 & 4.3 & 3960 & 3.1 \\
\hline 3 & SadduMowa & Phithophora spp. & $\mathrm{Gr}$ & MF & 910 & 4.5 & 3770 & 3.6 \\
\hline \multirow[t]{3}{*}{4} & Urla & Microcystis spp. & BGr & SF & 930 & 3.7 & 4070 & 2.8 \\
\hline & Urla & Hydrodictyon spp. & $\mathrm{Gr}$ & $\mathrm{MF}$ & 1000 & 3.1 & 4100 & 2.1 \\
\hline & Urla & Phithophora spp. & $\mathrm{Gr}$ & MF & 920 & 3.1 & 3780 & 3.1 \\
\hline \multirow[t]{2}{*}{5} & Siltara & Hydrodictyon spp. & $\mathrm{Gr}$ & MF & 1050 & 2.3 & 5250 & 2.6 \\
\hline & Siltara & Phithophora spp. & $\mathrm{Gr}$ & MF & 920 & 4.6 & 3800 & 3.6 \\
\hline 6 & Heerapur & Lyngbya spp. & $\mathrm{Gr}$ & MF & 1070 & 1.5 & 6200 & 1.4 \\
\hline 7 & Pachpedinaka & Phithophora spp. & $\mathrm{Gr}$ & $\mathrm{MF}$ & 930 & 3.7 & 3700 & 3.8 \\
\hline
\end{tabular}

$\mathrm{Gr}=$ Green, $\mathrm{BGr}=$ Blue green, $\mathrm{AB}=$ Algal bloom, $\mathrm{MF}=$ Mate form, $\mathrm{SF}=$ Scum form .

\section{Conclusion}

The calorific value of the sewage sludge is found to be similar to biomass and animal waste. The heat value of the sludge and algae was found to be comparable. The heat value of algal boom is seemed to be independent of quality of the sludge because it is produced by process of eutrophication.

\section{Acknowledgements}

We are thankful to our University for providing equipment grant to the SOS in Environmental Science.

\section{References}

[1] Sen, B., Alp, M.T., Sonmez, F., Kocer, M.A.T. and Canpolat, O. (2013) Relationship of Algae to Water Pollution and Waste Water Treatment. In: Elshorbagy, W. and Chowdhury, R.K., Eds., Water Treatment. 
http://www.intechopen.com/books/water-treatment/relationship-of-algae-to-water-pollution-and-waste-water-treatment

[2] Han, X., Niu, M., Jiang, X. and Liu, J. (2012) Combustion Characteristics of Sewage Sludge in a Fluidized Bed. Industrial \& Engineering Chemistry Research, 51, 10565-10570. http://dx.doi.org/10.1021/ie3014988

[3] Lee, D.H., Yan, R., Shao, J. and Liang, D.L. (2008) Combustion Characteristics of Sewage Sludge in a Bench-Scale Fluidized Bed Reactor. Energy Fuels, 22, 2-8. http://dx.doi.org/10.1021/ef700266q

[4] Zakaria, M.S., Hassan, S. and Nor, M.F.M. (2015) Calorific Value of the Sewage Sludge in the Thermal Dryer. ARPN Journal of Engineering and Applied Sciences, 10, 10245-10248.

[5] Chen, W.-S., Chang, F.-C., Shen, Y.-H. and Tsai, M.-S. (2011) The Characteristics of Organic Sludge/Sawdust Derived Fuel. Bioresource Technology, 102, 5406-5410. http://dx.doi.org/10.1016/j.biortech.2010.11.007

[6] Supatata, N., Buates, J. and Hariyanont, P. (2013) Characterization of Fuel Briquettes Made from Sewage Sludge Mixed with Water Hyacinth and Sewage Sludge Mixed with Sedge. International Journal of Environmental Science and Development, 4, 179-181. http://dx.doi.org/10.7763/IJESD.2013.V4.330

[7] Chia, M.A, Lombardi, A.T. and Graça Gama Melão, M. (2013) Calorific Values of Chlorella vulgaris (Trebouxiophyceae) as a Function of Different Phosphorus Concentrations. Phycological Research, 61, 286-291. http://dx.doi.org/10.1111/pre.12026

[8] Paine, R.T. and Vadas, R.L. (1969) Calorific Values of Benthic Marine Algae and Their Postulated Relation to Invertebrate Food Preference. Marine Biology, 4, 79-86. http://dx.doi.org/10.1007/BF00347036

[9] Lamare, M.D. and Wing, S.R. (2001) Calorific Content of New Zealand Marine Macrophytes. New Zealand Journal of Marine and Freshwater Research, 35, 335-341. http://dx.doi.org/10.1080/00288330.2001.9517004

[10] Ghayal, M.S. and Pandya, M.T. (2013) Microalgae Biomass: A Renewable Source of Energy. Energy Procedia, 32, 242-250. http://dx.doi.org/10.1016/j.egypro.2013.05.031

[11] Kailas, A.P. and Nair, S.M. (2015) Comparison of Nutrient Compositions and Calorific Values of Eight Tropical Seaweeds. Phykos, 45, 62-74.

[12] APHA (2005) Standard Methods for Examination of Water and Waste Water. 21st Edition, APHA, Washington DC.

[13] IAEA-TECDOC 1360 (2003) Collection and Preparation of Bottom Sediment Samples for Analysis of Radionuclides and Trace Elements.

[14] ASTM International, Vienna (2008) ASTM Standard D2395-2007a: Standard Test Methods for Specific Gravity of Wood and Wood-Based Materials. ASTM International, West Conshohocken.

[15] ASTM International (2008) ASTM D 1102-84, Test Method for Ash in Wood. Annual Book of ASTM Standards, 153-154.

[16] ASTM International (2012) ASTM Standard E711-87, Standard Test Method for Gross Calorific Value of Refuse-Derived Fuel by the Bomb Calorimeter. http://ia600806.us.archive.org/23/items/gov.law.astm.e711.1987/astm 